\title{
International Organizations, Changing Governance and China's Policy-making in Higher Education: An Analysis of the World Bank and the World Trade Organization
}

\author{
Rui Yang \\ Comparative Education Research Centre \\ University of Hong Kong
}

\section{Introduction}

Globalization, as a description of both putatively real processes and certain kinds of discourses (Urry, 1998), has been taken as a salient feature of our times in significant modern and postmodern social theories. One way to define globalization is to focus on the multiplicity of linkages and interconnections that transcend the nation state, a process through which events, decisions and actions in one part of the world affect actions in other parts of the world. Time and space are reordered so that authority structures are no longer fixed to territory (Held et al., 1999). This view stresses the importance of international governmental organizations and non-governmental organizations as influencers and shapers of the global environment. It posits that the establishment of international institutions has become a central feature of modern international politics (Koremenos et al., 2001). Participation in international organizations, which is itself often used as an indicator of integration into the wider world system, may lead to the active incorporation of nation-states with worldwide connotations.

In higher education, nation-centric policies are no longer sufficient and cannot adequately engage with the new global realities of transnational economic, political and cultural interconnectivities. Educational ideologies and experience now circulate around the world at a rapid rate, resulting in global educational policy networks that are often more influential than local political actors. Similar pressures, procedures and 
organizational patterns increasingly govern educational systems, leading to “universalizing tendencies in educational reform” (Halpin, 1994, p. 204). Consequently, there is a global convergence of educational policy being placed highly on the agendas of national governments and international organizations.

Located within the same neo-liberal imagery, the scope, depth and similarity of changes occurring in a wide variety of nations with different social, historical and economic characteristics are unprecedented (Schugurensky, 1999). While the actual dynamics and pace of change vary across national systems, the direction of change appears to be similar. Why has today's grand narrative of economic globalization acquired the status of a universalistic logic that supposedly propels and legitimizes such practices of managerialism as downsizing and state deregulations and privatization, as if they were a natural and inevitable response to the steering logic of globalization (Rizvi, 2004)?

International organizations are part of the answer. They play an increasingly important role in the processes of educational policy formation and evaluation at the national level, involving negotiating consensus and conventions, ensuring coordinated policy action across national systems, as well as supporting international cooperation in education through the development of global indicators and quality. The approaches driven by such organizations indicate a trend towards uniformity, demanding a convergence in thinking and accepting similar diagnoses of problems confronting educational systems with widely differing social, political and economic traditions. They influence national systems through a number of normative and rule-creating activities (Jacobson, 1984). The specific activities that show the relevance of international 
organizations for worldwide educational policy convergence include the exchange of information, charters and constitutions, standard-setting instruments, technical and financial resources (McNealy \& Cha, 1994).

With the help of the functioning of international organizations, the neoliberal imagery of globalization has acquired ascendancy in education thinking and become highly normative. It designates certain power relations, practices and technologies, playing a hegemonic role in organizing and decoding the meaning of the world. Its dominance is secured through a range of political strategies, employed by international organizations and national governments alike. In the context of such multilateralism, developing countries are often coerced to take into account the alleged 'imperatives of the global economy.' The restructuring of higher education worldwide informed by neoliberal market ideologies has transformed the framework of the broader changes in policy and governance, and has had an impact on the manner in which universities are financed and managed (Rizvi, 2004).

Increasing international activities in the arena of education raise the question as to what extent international organizations are complementing or even partly taking over the design and provision of education policies. Using examples from higher education practices from the People's Republic of China (PRC), this article explores the role played by international organizations in the transformation of mode of governance in China's higher education. More specifically, it examines how international organizations "lend" their ideas for circulation, and how the local and the global play out. It analyzes what circulates internationally as "reforms" and its impact on the actors that move and 
translate such practices into local contexts, exploring the relation of the global in local situations and the complex impact of policy borrowing.

\section{International Organizations and China's Policy-making in Higher Education}

China has a long, rich history of education. By the close of the $18^{\text {th }}$ century, China had perfected one of the world's most durable political systems during 2000 years of its imperial history and had developed a unique civilization that had deeply influenced the culture of its neighboring countries. China's policy-making in higher education during its long period in history rarely used others systems as its frame of reference. Instead, China served as a centre of education with powerful regional influence (Yang, 2002). Higher education had evolved according to its own logic and never deviated from its developmental path, despite external influences. Higher education circles confined their dissemination of knowledge to a provincial level and persisted in disregarding knowing anything of the rest of the world. Over a long historical process, a unique set of scholarly values arose in China. There was no institution in Chinese tradition that could be called a university (Hayhoe, 1996).

However, China experienced devastating humiliation for at least one and a half centuries starting from the Opium Wars (1840-1842) when Western powers looted China. To save the country, Chinese officials and academics were forced by the times to accept the superiority of Western education. China became a pure education importer from the mid- $19^{\text {th }}$ century. Educational policy-makers started to look at major Western countries and Japan for innovations and standards. This has often led China's policy-making to 
lean to one side, for example, to the former Soviet system in the 1950s and to the American system in the 1990s. Such a situation has remained largely unchanged.

Since its opening up to the world in the late 1970s, multilateral collaboration with international organizations has been an important part of China's foreign policy in education. Such collaboration with international organizations has changed substantially China's higher education policy-making. Within the past three decades or so, China has worked in particular with the United Nations Educational, Scientific and Cultural Organization (UNESCO), the World Bank, the European Union (EU), the Organization for Economic Co-operation and Development (OECD), the Asia-Pacific Economic Corporation (APEC), and the Association of Southeast Asian Nations (ASEAN), and the WTO. China has had a politically complicated relationship with the United Nations, with the Republic of China (ROC) having served as a founding member nation of the UN, the tension between the ROC and the ruling People's Republic of China (PRC) government in the 1950s and 60s, and, finally, ultimate recognition of the PRC as the legitimate representative of China's international interests in 1971. Since then, China and has contributed substantially to the member organizations of the UN family. In 1980, China began to work with the United Nations Development Program (UNDP) in education. The UNDP provided China with much needed technology and financial assistance, which allowed China to invite foreign experts to China and to organize overseas trips for the Chinese scholars and officials. The collaboration has focused on basic and vocational education, especially on the provision of technical training including English proficiency, research and administration at higher education institutions, teaching and management in schools, and in-service vocational training. China has also collaborated with the UNICEF 
almost exclusively within areas directly involved in children and schools, with particular stress on projects of children's health protection (Ye, 2004, pp. 1065-1066).

As one of the 20 founding members of UNESCO, China's collaboration with the UNESCO has included broader topics, as well. The National Commission of the People's Republic of China for UNESCO was established on 19 February 1979. China has been actively participating in the regular activities organized by the UNESCO (Yu et al., 2001, p. 311), attending the World Conferences on Education, working jointly on the projects related to education at all levels with particular emphasis on basic literacy campaign, translating and distributing UNESCO publications such as The UNESCO Courier, Prospects, and the International Social Science Journal, and exporting China’s experience in the fields that China has achieved highly such as lowering illiteracy for rural development. This relationship with UNESCO is the most balanced of China's partnerships with global organizations. Other collaborations, such as those with the World Bank and the World Trade Organization (WTO) have proven to be simultaneously critically important and fundamentally challenging.

\section{The World Bank}

Through the Washington Consensus, which advocates market fundamentalism, international financial organizations exert their great influence especially on developing countries. The World Bank, for example, projects its influence mainly through its financial assistance, with definite requirements for specific attitudes of and approach to educational development. The bank-supported projects are not always as successful as 
expected. Indeed, they have been criticized for not being able to lead the recipient countries to modernization.

The World Bank, described in much detail in earlier chapters, is a development Bank that provides loans, policy advice, technical assistance and knowledge sharing services to low and middle income countries. It works with client countries and other partners and strives to be strategic in its lending, research, advice, and where feasible, to address issues through regional initiatives and other programs. The Bank has transferred about US\$36.5 billion in loans and credits for education. In the Asia Pacific region, the Bank works with over 20 clients on education issues (World Bank, 2006).

Since the first loan in 1981 supporting development of Chinese universities, the World Bank’s cumulative lending to China for a total of 284 development projects involving education was close to US $\$ 42.2$ billion as of June $30,2007,70$ of these projects remain active, making China's portfolio one of the largest in the Bank. World Bank-supported projects can be found in almost all parts of China and in many sectors of the economy (World Bank, 2008).

China's first collaboration with the Bank was in 1980, and higher education was the most important part among all the projects supported by the Bank during the 1980s. The first project involved 183 high education institutions, which was one-fifth of the entire number of Chinese higher institutions at that time. The project was approved by the Chinese government in November 1981, and started from February 1992. The Bank’s financial aid reached US \$200 million to increase undergraduate and postgraduate enrolments in Chinese universities. It aimed to improve teaching quality, enhance research capacity and strengthen science and engineering education in 28 key universities. 
By June 1985 when the project was completed 2,471 people from 28 institutions had been sent overseas for training.

The second project focused on 39 higher education institutions. It started from July 1985 and completed by the end of 1991. Assisted by a loan of 145 million US dollars from the Bank, the Chinese institutions improved their teaching and research facilities and educational quality. A large number of people received high level training including more than 800 and 9,000 respectively at doctoral and Masters levels. Many faculty members were sent overseas for training.

During the 1980s, at the invitation of the Chinese government, the Bank conducted two events specifically for China with particular influence on China's higher education policy-making. The first was an on-the-spot investigation by a delegation consisted of bank officials and advisors during 1993-1994. The report, China: Higher Education Reforms, was released in 1995. Based on an analysis of some major issues in China's higher education development, the report emphatically offered some policy recommendations, suggesting that China encourage the diversification of higher education institutions; build up a mechanism to encourage public universities to take the initiative to diversify their sources for resources; redefine the role of the state in the higher education sector; and prioritize the principles of quality and equality in policy design. The advices became highly influential in the Chinese higher education circle. The other event was an investigation into China's higher education by bank experts in January and May 1998 and July 1999. Based on the 1995 reform paper, the Bank published the report Strategic Goals for Chinese Education in the $21^{\text {st }}$ Century in 1999 (World Bank, 1999). It emphasized the strategic role of education in the intense 
competition of the $21^{\text {st }}$ century. The report defined a few principles for Chinese higher education reforms including: (1) defining the role of the state in higher education as policy-making, target-setting, and supervision and administration; and (2) creating an environment for higher education institutions to enjoy more autonomy in their finance and management. It also offered some specific suggestions about higher education development in China.

China's higher education policies issued after 1997, such as the Higher Education Law of the People's Republic of China (1998), were highly in line with World Bank suggestions: (1) the structural reform of Chinese higher education was based on the Bank’s recommendation for the central government to achieve macro adjustment through policy-making and planning, with devolution of power gradually from the central to provincial governments and clearly-defined roles of the central government and higher education institutions; (2) higher education institutions were amalgamated to have efficiency and better use of resources; (3) higher education institutions were granted much more autonomy in student admissions; (4) policies of student loans were implemented quite rapidly to share the costs in the massification of higher education; (5) higher education institutions were allowed to develop their strategic planning; (6) funding modes changed to reward efficiency; (7) academic and research environment were improved to avoid brain drain; (8) more attention was paid to quality assurance and evaluation exercises. Although leaders of higher education institutions occasionally raised some objections, bank policy suggestions were almost entirely accepted by the Chinese government (Wang, 2001). 
While it remains highly difficult to determine accurately how far the World Bank’s propositions have directly influenced Chinese higher education, many correlations appear to demonstrate the influence. For example, the Bank’s (1999) report Strategic Goals for Chinese Education in the $21^{\text {st }}$ Century set forth some strategic goals for improving Chinese higher education, with comments and suggestions under each strategy. One suggestion was to increase higher education enrolments massively. The expansion of higher education enrolments thereafter became one of the most important recent policies. From 1999 to 2001, the number of Chinese university enrolments nearly doubled. The strikingly similar contents between the Chinese higher education policies and the Bank's suggestions demonstrate that the reform and development of China's higher education since the $1980 \mathrm{~s}$ in the $20^{\text {th }}$ century has been a process in which the impact of the World Bank on Chinese higher education grew from elementary to profound, with an ascendance of the Bank's legitimacy in the Chinese society. The Bank has played a role of “director" or a "guide” (Xu, 2006, p. 15).

Unlike the relations described earlier between the UN agencies and China, the World Bank's relation to China has not been an equal partnership (Drake, 2001). A few Chinese scholars have noticed this and begun to question the impact of the Bank on higher education in the recipient countries (Xu, 2000; Ding, 1991). Their views are, however, based exclusively on what has been published in the English literature and short of empirical support. Their voice has been fairly thin, and their number small. But their warning deserves more attention from their peers and the government.

As one of the largest countries in the world, China has its sufficient centre of gravity to operate with relative autonomy (Yang, 2002). Compared with many other 
developing countries, China has won certain control over the bank-aided projects, and China’s collaboration with the Bank has been overall successful. Meanwhile, the Bank's assistance has always had a significant impact on Chinese higher education right from the early days of China's reform and development (He, 1996). One particular example is the training of experts. During 1982-1994, 7,000 people were able to travel overseas for training or further studies, 600 attended conferences or conducted investigations abroad, and 100,000 received training within China (Department of International Cooperation and Exchange, Ministry of Education of the People’s Republic of China, 1998, p. 225). Many of them were in higher education. The trained professionals have been the policy makers and implementers of China's fast higher education development (Hayhoe, 1996). More fundamentally, the Bank has been significant in bringing in fresh, sophisticated education policy ideas and values, especially by inviting the participation of renown experts to be on international advisory panels and by appointing well-qualified international scholars to visit project universities.

\section{The World Trade Organization}

China's economic reforms qualified China for membership in a number of international economic organizations. It became an observer of the General Agreement on Tariff and Trade (GATT) in 1952 and formally applied for full GATT membership in July 1986. The $8^{\text {th }}$ International Trade Round, the so-called Uruguay Round (1986-1994) replaced the GATT with the WTO. GATT Member-States had determined that international trade could be increased by structuring agreements similar to the GATT that focus on trade in areas other than goods such as services. Thereupon, three multilateral agreements became 
the pillars within the framework of the new World Trade Organization: the General Agreement on Tariff and Trade, the General Agreement on Trade in Services (GATS), and the General Agreement on Trade-related aspects of Intellectual Property Rights (TRIPS).

According to GATS, apart from educational activities completely subsidized by the government, all educational programs that charge tuition fees and have commercial purposes fall under the educational service trade; all WTO signatory countries are entitled to compete to offer educational services and organize various educational and training activities via tele-education, launching wholly foreign-owned or joint-venture schools, relaxing policies for studying abroad and the free flow of professionals. WTO rules stipulate that "educational-service" related activities have nothing to do with tariffs and trade barriers. The aim of such activities is to encourage member countries to reform restrictive educational laws and facilitate the educational service trade. The educational service trade is carried out in four ways:

(1) Cross-border supply. Educational service suppliers in a member country offer educational services to consumers in other member countries through the Internet or by correspondence.

(2) Consumption abroad. Educational service suppliers in a member country offer educational services, such as studying and receiving training abroad, to customers from another member country.

(3) Commercial presence. Educational service suppliers from a member country open commercial or professional institutions, such as schools, in another member country. 
(4) Flow of natural persons. Educational service providers from a member country enter into another member country to provide educational services, such as foreign teachers now teaching in China, or Chinese teachers now teaching abroad. China became a formal member of the WTO on 11 December 2002, after 15 years of painstaking negotiations. China's accession implies recognition of the economic benefits of integration to the world economy. It is seen as a means for accelerating economic restructuring and reform, and hence creating the appropriate conditions for further modernization of the country and its long-term growth. China's education would not change dramatically immediately after the accession. The impact of the entry on China's education would be long-term especially in higher education (Wang \& Gao, 2000). Since the beginning of this century, managing the influence of the WTO has become a significant challenge for China's higher education policy makers and leaders.

A more liberal educational service trade was a promise China made upon its entry into the WTO. However, as education is an issue that has a bearing on state sovereignty, public morals and inheritance of national culture, all countries are cautious in opening their education sector, especially elementary education. China is no exception. In relation to educational services, China's WTO-entry promises fall into four fields:

(1) China makes no promises to open its national compulsory education and special education services, such as military, police, political and Communist Party of China Party school education.

(2) China imposes no limitations on sending students abroad for studying and training, nor on receiving foreign students. 
(3) China promises to partly open its higher education, adult education, high school education, preschool education and other education services. Foreign educational service suppliers are allowed to launch joint educational institutions or joint schools in China, with foreign majority ownership permitted. Foreign education service suppliers are forbidden to offer education services independently, and joint schools in China must observe the Regulations on Sino-Foreign Joint Schools.

(4) Foreign individual educational service suppliers may enter China to provide educational services when invited or employed by Chinese schools and other educational institutions on the condition that they possess a Bachelor's degree or above and an appropriate professional title or certificate, including two years of professional experience.

Although China has promised foreign education institutions access to its educational service market via a "commercial presence” and “majority ownership," this does not necessarily mean foreign educational institutions can violate China's existing non-profit principle for the educational industry. China only promises "market access” and a guarantee of "management rights."

With its entry into the WTO, China chose to open its markets further and to participate in the mainstream development of the international economy, resulting in both challenges and opportunities. One challenge is a variety of potential imbalances of educational programs at different levels in various regions caused by the commercial entry of foreign higher education into the China market. The scale of foreign activity in China has been increasing steadily. In 1995, there were only two programs that could 
offer an overseas degree. By 2002, the foreign backed programs had spread to China’s 28 provinces. Their numbers increased to 745 , with 169 programs qualified to award overseas (including Hong Kong) degrees by June 2004 (Ministry of Education, 2004).

The fast growth of transnational programs under direct influence of the WTO has challenged the longstanding ways of policy-making and governance in China's higher education, especially in the following areas:

Firstly, in terms of academic programs, the disciplinary distribution of those programs tends to favor certain subject areas. English language programs were popular in the 1970s, science and technology was in high demand in the 1980s and 1990s, and business and management has become the most desirable in the last 10 years (Zhang, 2003). $61.02 \%$ of coursework is in the broad area of business and management, followed by IT (13.56\%), engineering (7.91\%), education (7.34\%), law (2.26\%), sports management (1.69\%), real estate (1.69\%), English language (1.13\%), and 0.56\% each for psychology, architecture and a few others. This echoes Tan’s (2006) finding that among the 136 undergraduate joint programs, 67 (49.3\%) were in business and management, with 4,075 (54\%) of the national total of 7,549 students.

Geographically, most of the programs are concentrated in the eastern coastal areas, the most economically prosperous region in China. Of the 47 higher education institutions with joint undergraduate programs with overseas partners in 2004, 32 (68.1\%) were in the costal east, only 2 (4.3\%) in the west. Similarly, 35 (74.5\%) of the 47 institutions with joint programs in tertiary vocational and/or technical education were in the east, only 4 (8.5\%) were in the west (Tan, 2006). The regional distribution is as follows: Beijing (28.92\%), Shanghai (19.28\%), Tianjin (7.83\%), Zhejiang (7.23\%), 
Jiangsu (6.02\%), Jiangxi (4.82\%), Liaoning (4.22\%), Guangdong (4.22\%), Heilongjiang (3.01\%), Hubei (2.41\%), Yunnan (2.41\%), Shaanxi (1.81\%), Jilin (1.81\%), Sichuan (1.81\%), Hebei (1.2\%), Fujian (1.2\%), Henan (0.6\%), Shanxi (0.6\%), and Guizhou (0.6\%). In 2004, there had been no officially listed joint program in some other provinces such as Anhui, Gansu, Guangxi, Hainan, Inner Mongolia, Ningxia, Qinghai, Tibet and Xinjiang, all of which are relatively much underdeveloped. The Chinese government has noticed both the disciplinary and geographical imbalances. Yet, it has been restricted by market forces to change the situation as it intends.

Secondly, with regard to quality assurance, growing evidences show that transnational provision of higher education is in many cases driven by market opportunity and that compromises to quality are widespread (Tierney, 2001; Lieven \& Martin, 2006). With the recent global rise of transnational programs, quality assurance has become a major issue for those program offering institutions. At this stage with little international agreement on standards, stronger national regulation, rather than the liberalization demanded by Alderman (2002) and others, is needed. An unregulated market allows overseas 'for-profit' operations to offer poor quality higher education.

Quality assurance issue has also been raised in China. Most recently, the Ministry of Education issued a further notice to regulate overseas education programs on 6 April 2007, expressing strong concerns about the quality control of joint education programs. It decided not to approve any new programs, in principle, by the end of 2008. Indeed, it even forced 64 joint programs in Shanghai to close down.

According to Chinese regulations, the government takes legal responsibilities for approving or chartering the establishment of transnational education programs in line 
with the existing legal frameworks and guidelines. The problem, however, lies at the lack of consistent intervention after the approval. The responsibility for quality assurance in effect falls almost entirely into the hands of the involved individual teaching staff and their program coordinators (Huang, 2007). Chinese students enrolled in the joint programs are, therefore, concerned about the quality of their programs, especially when individual teachers and their departments are the only ones to take up quality assurance responsibilities. It seems that the old regulatory frameworks Chinese government has been using have become increasingly ineffective in a much changed situation.

Thirdly, an even more evident illustration of the challenge is educational sovereignty. With the increasing scale of foreign activity in higher education in China, there is a genuine concern about the potential loss of educational sovereignty (Wang \& Xue, 2004). Despite the fact that the issue of educational sovereignty has never stopped perplexing Chinese policy-makers, theorists and partner institutions, and that such a concern is not China-specific (Adam, 2001), Chinese institutions' collaboration and competition with educational institutions from different nations under the same rules and regulations is seriously challenging China as a sovereign state to defend its sovereignty while abiding by these rules and regulations (J. X. Wang, 2002). International financial organizations have played a significant role here, due to their proposition of denationalization and deregulation. Nation-states leave their education rights increasingly to the market and to international organizations. China's accession to the WTO means it agrees to potential WTO intervention in its domestic education policy. This was why the Chinese government modified the legislations governing transnational education in China in 2003 (Garrett, 2004). It is therefore increasingly difficult for China to maintain its 
traditional sense of sovereignty. Its longstanding notion of education as an internal affair that should be immunized from any external interference no longer holds. The Chinese government needs to relax control over its education market, devolve power to institutions.

\section{Transforming Modes of Governance in China's Higher Education}

Global forces are now commonly cited as governing discourses to justify governmental policy options. Within this policy context, Chinese universities started to change their governance model along business lines. By the late 1990s, through implementing decentralization and marketization, China had initiated fundamental changes especially in the orientation, finance and management of higher education. The market had entered into government-university relationships in China to form a "trinity" (Dong, 2003), a reform that has been finance-driven (Carnoy, 2000), subjecting education to the language and logic of neoliberal economics as part of a larger process of commoditisation (Dale, 2000).

As the most influential international financial institutions, the cooperation of the WB and WTO with China has successfully pushed their particular ideology-market fundamentalism-to be accepted in the Chinese higher education circle. Their impact on China in general and on Chinese higher education in particular has become increasingly evident (Xu, 2006), especially after China’s entry into the WTO. Market ideologies are burgeoning in the Chinese higher education sector. It is now politically correct in China to advocate market-driven reform in education. The dominant view underlying China's 
policy-making is that it respects 'natural laws of a market economy' including businessstyle management, market-oriented operations, and commercially viable products. This view is favored by Chinese mainstream scholars who argue that it is a correct way to run education as an industry in order to lead China's education onto a right path because issues involving supply and demand must be handled according to market rules, and education is no exception. User-pays education is encouraged. One of the advocates, Lao Kaisheng (2003), for example, frequently cites the WB and WTO to justify this view.

Within such a context, public universities are made into commodity producing enterprises, what Rikowski (2003) refers to as “capitalization.” Chinese universities have now been pushed by the government to change their governance paradigm to adopt a doctrine of monetarism characterized by freedom and markets replacing Keynesianism. The role of the state has been changing from a provider of welfare benefits to a builder of market roles (Sbragia, 2000). Introducing market principles and practices to manage the public sector has inevitably transformed the society into an "audit society” (Power, 1997), or "performative society" (Ball, 2000), turning the socialist states into a competitive state (Cerny, 1996), or an evaluative state which attaches importance to effectiveness, efficiency and economy in public sector management (Henkel, 1998; Kogan \& Hanney, 2000).

Similar to the situation in many countries (Slaughter \& Leslie, 1997; Braun \& Merrien, 1999), this change in governance ideology in higher education has altered the ways in which Chinese universities are managed. The Chinese government now encourages educational institutions to raise additional income and reinterprets its 
responsibilities for higher education. In order to expand its higher education, China has adopts an approach to mass higher education to diversify its channels for resources. Universities are increasingly urged to cooperate with the private sector, and respond to market needs (World Bank, 1997). Private institutions are bound to play a significant role.

Indeed, the private sector has become increasingly evident in China both within and without higher education (Bray, 1998). Under the impact of global market forces, there has been a seemingly general trend towards the reduction of per capita public funding to higher education, despite the continuing increase in student enrollments (Johnstone, 1998). Money everywhere is scarce. China is no exception. The funding higher education is being increasingly shifted to the shoulders of the individual. Nongovernmental funding sources are becoming crucial. Private institutions are resurging like bamboo shoots after a spring rain, as it is often referred to in China. By 2000, there has been over 1,400 private colleges and universities serving over one million students (Xie, 2001, p. 184). By April 2008, the overall number of such institutions totaled 295, with 43 being able to confer Bachelor degrees. While the number of those that have been accredited by the central government remains small, the status of China's private higher education is becoming increasingly legitimate. Their governance demands some new regulatory frameworks.

In response to both external influences and internal demands and conditions, China has adopted the following governance approaches to expand its higher education scale. Their long-term repercussions, however, remain to be seen.

First, individuals and enterprises are encouraged more to establish post-secondary institutions. At present, when a private institution is founded, it is hard to attend to each 
and every aspect of a matter. It is the responsibility of the Chinese governments at various levels to give support to improve the institution's operation. To achieve this, some specific policies and regulations are called for. With the Higher Education Law issued in 1998, China has made a good start in this regard.

Secondly, within one single institution, it is now possible to operate on a basis of one university, two systems. A private institution can be built up with affiliation to a public university. By so doing, the parent university can be directly involved in the quality assurance at its affiliated private institution, while graduates from the institution can be conferred qualifications by the parent university. There have been more than 319 such institutions scattered in its provinces and 27 provincial-level municipalities.

Thirdly, education shares are being tried out. The stock market is closely associated with the free market economy. Education shares have been reported as an effective way to raise education funds. Some private institutions are operated as businesses. According to a few publications in China, this can improve teachers' morale and help maintain the stable development of these institutions. Hualian University at Guangzhou, for example, successfully solved its funding problems and financially benefited its shareholders (Xie, 2001, p. 186). In 1998, Zhejiang formulated a policy to specifically allow funds to be raised by means of education shares.

\section{End Remarks}

Within the previous years, international organizations have mobilized ideologies and practices in China by promoting certain ideas and information often in the form of "expert consultants.” China has shown impressively its cooperation to adhere to the 
values and standards expressed by international organizations. In order to gain financial resources and technical assistance, China has worked hard to meet the conditionality that is linked with adoption of those ideas and values and the corresponding policies, and learnt from the knowledge and practices that are almost exclusively based on Western experience. By the 1990s, China's memberships of international organizations had reached more than $80 \%$ of those of the United States, with China considered "an active participant” by most institutions (Johnston, 2001). Such efforts, which have been critically important for China's higher education governance and policy-making, are expected to continue.

With a fast integration into the global community-economic, socially, culturally, and politically, China's people are changing their frame of reference in higher education and are looking at the international community for policy innovation and solutions to their development problems. China's higher education reform ideas emerged from the influence and policy objectives promoted by international lenders such as the World Bank, and multinational organizations including UNESCO and the OECD. Since the 1980s, projects supported by international organizations such as the World Bank have greatly influenced China's policy and governance in higher education. China's entry into the WTO ensures that international rather than traditional domestic approaches to higher education will be used much further.

As Diehl (2001) points out, international organizations are neither irrelevant nor omnipotent in global politics. They play important roles but their influence varies according to the issue area and situation confronted. Just as it did in order to achieve the overwhelming athletic and organizational successes of the 2008 Summer Olympic games, 
China needs to learn to master the rules of engagement for international higher education, which are deeply rooted in Western cultures. To be a real world champion in higher education, China faces many challenges ahead, but if past experience is an indicator, one of the most effective strategies it may utilize to achieve international higher education relevance and success is to work more closely with international organizations, to maximize its potential as a major global economic and knowledge development player.

References Retrieved from "http://en.wikipedia.org/wiki/New_Culture_Movement"

Adam, Stephen. Transnational Education Project: Report and Recommendations. Brussels: Confederation of European Union Rectors’ Conference, 2001. Alderman, Geoffrey. “Lots to gain from for-profit.” Times Higher Education Supplement, 22 March 2002.

Ball, Stephen J. "Performativity and fragmentation in "postmodern schooling.” In Postmodernity and Fragmentation of Welfare, edited by J. Carte. London and New York: Routledge.

Braun, Dietmar. and Merrien, Francois-Xavier (eds.), Towards A New Governance for University? A Comparative View. London: Jessica Kingsley Publishers, 1999. Bray, Mark. Financing Education in Developing Asia: Issues, Trends and Policy Implications. Manila: Asia Development Bank, 1998.

Carnoy, Martin. Sustaining the new economy in the Information age: Reflections on our changing world University Park, PA: The Pennsylvania State University Press, 2000. 
Cerny, Philip G. "Paradoxes of the Competition State: The Dynamic of Political Globalization.” Governance and Opposition 32(2) (1996): 251-271.

Dale, Roger. “Globalization: A New World for Comparative Education.” In Discourse formation in comparative education, edited by J. Schriewer. New York: Peter Lang, 2000.

Department of International Cooperation and Exchange, Ministry of Education of the People’s Republic of China. Foreign Affairs in Education: Historical Evolutions and Current Policies. Beijing: Beijing Normal University Press, 1998.

Diehl, Paul F. The Politics of Global Governance: International Organizations in an Interdependent World. London: Lynne Rienner Publishers, 2001.

Ding, Bang-ping. “A Summary of Comparative Education Research Abroad.” Foreign Education Trend 1 (1991): 15-19. (In Chinese)

Dong, Yun-chuan. “Trinity: The Relationship between the University, Government and Society.” Fudan Education Forum 1(6) (2003): 6-9. (In Chinese)

Drake, Earl. "World Bank Transfer of Technology and Ideas to India and China.” In Knowledge Across Cultures: A Contribution to Dialogue Among Civilizations, edited by R. Hayhoe and J. Pan. Hong Kong: Comparative Education Research Centre, University of Hong Kong, 2001

Garrett, Richard. "Foreign Higher Education Activity in China.” International Higher Education Winter(2004): 21-23.

Halpin, David. "Practice and Prospects in Educational Policy Research.” In Researching Educational Policy: Ethical and Methodological Issues, edited by D. Halpin and B. Troyna. London: Falmer Press, 1994. 
Hayhoe, Ruth. China's Universities 1895-1995: A Century of Cultural Conflict. New York: Garland, 1996.

He, Dong-chang. Contemporary Chinese Education. Beijing: Contemporary China Publishing House, 1996. (In Chinese)

Held, David, et al., Global Transformations. Stanford, California: Stanford University Press.

Henkel, Mary. "Evaluation in Higher Education: Conceptual and Epistemological Foundations.” European Journal of Education 33(2)(1998): 283-297.

Huang, Fu-tao. "Internationalisation of Higher Education in the Developing and Emerging Countries: A Focus on Transnational Higher Education.” Journal of Studies in International Education 11(2007): 421-32.

Jacobson, Harold K. Networks of Interdependence: International Organisations and the Global Political System. New York: Alfred A. Knopf, 1984.

Johnston, Alastair I. “Summary of Research on China’s Relations with International Institutions.” World Economy and Politics 8(2001): 48-53. (In Chinese)

Johnstone, Bruce. The Financing and Management of Higher Education: A Status Report on Worldwide Reforms. Paper presented at the UNESCO world conference on higher education, Paris, France, 5-9 October, 1998.

Kogan, Maurice. and Hanney, Stephen. Reforming Higher Education. London and Philadelophia: Jessica Kingsley Publishers, 2000.

Koremenos, Barbara., Lipson, Charles. and Snidal, Duncan. "The Rational Design of International Institutions.” International Organisation 55(2001): 741-99. 
Lao, Kai-sheng. "Challenges to the Public-welfare Nature of Education.” Educational Research 24(2) (2003): 3-9. (In Chinese)

Lieven, Michael. and Martin, Graeme. "Higher Education in a Global Market: The Case of British Overseas Provision in Israel.” Higher Education 52(2006): 41-68.

McNeely, Conniel L. and Cha, Yun-Kyung. "Worldwide Educational Convergence through International Organisations.” Education Policy Analysis Archives 2(1994). Retrieved 23 April 2002 from http://epaa.asu.edu/epaa/v2n14.html

Ministry of Education. "List of Joint Programmes Leading to Degrees of Foreign Universities and Universities in Hong Kong.” 2004. Retrieved February 18, 2008, from http://www.cfce.cn/web/List/Info/200603/20.html

Power, Michael. “The Audit Society: Rituals of Verification.” Oxford: Oxford University Press, 1997.

Rikowski, Glenn. “The Business Takeover of Schools.” Mediaactive: Ideas Knowledge Culture 1(2003): 91-108.

Rikowski, Glenn. “The Business Takeover of Schools.” Mediaactive: Ideas Knowledge Culture 1(2003): 91-108.

Rizvi, Fazal. “Theorising the Global Convergence of Educational Restructuring.” In Educational Restructuring: International Perspectives on Travelling Policies, edited by S. Lindblad and T.S. Popkewitz. Greenwich, Connecticut: Information Age Publishing Inc, 2004.

Sbragia, Alberta M. "Governance, the State, and the Market: what Is Going on.” Governance 13(2000): 243-250. 
Schugurensky, Daniel. "Higher Education Restructuring in the Era of Globalisation:

Toward a Heteronomous model?” In Comparative Education: The Dialectic of the Global and the Local, edited by R. Arnove and C.A. Torres. Lanham: Rowman \& Littlefield, 1999.

Slaughter, Sheila. and Leslie, Larry L. Academic Capitalism: Politics, Policies and the Entrepreneurial University. Baltimore, New Jersey: Johns Hopkins University Press, 1997.

Tan, Mei-qiong. “Chinese-foreign Joint Higher Education Provision: Current Situation and Policy Suggestions.” Journal of Higher Education 27(2006): 34-39. (In Chinese)

Tierney, William G. “Academic Freedom and Organizational Identity.” Australian Universities’ Review, 44(2001): 7-14.

Urry, J. Scott, P. (ed) Contemporary transformations of time and space. The globalisation of higher education pp. 1-17. Buckingham, UK: Open University Press/SRHE , 1998.

Wang, Jian-bo. and Xue, Rui-li. “Some Reflections on Educational Sovereignty in Chinese-foreign Joint Programs.” Journal of Shandong Normal University (Humanities and Social Sciences), 49(2004): 119-122. (In Chinese)

Wang, Jian-xiang. “How to Maintain Our Country’s Educational Sovereignty in the Process of Opening Education Market.” Journal of Hebei Normal University (Educational Science Edition) 4(2002): 5-8.

Wang, Ying. Higher Education Reform in China. Ed.D. Dissertation, Baylor University, 2001. 
Wang, Ying-jie. and Gao, Yi-ming. “Internationalisation: An Important Theme of China's Higher Education in the $21^{\text {st }}$ Century.” Tsinghua Education Research 2(2000): 13-16. (In Chinese)

World Bank. China: Higher Education Reform. Washington, D.C.: World Bank, 1997. World Bank. Overview of China's Projects and Programs, 2008. Retrieved 10 August 2008 from http://web.worldbank.org/WBSITE/EXTERNAL/COUNTRIES/EASTASIAPACIF ICEXT/CHINAEXTN/0,,contentMDK:21564436 menuPK:318982 pagePK:1497 618 piPK:217854 theSitePK:318950,00.html

World Bank. Strategic Goals for Chinese Education in the $21^{\text {st }}$ Century, 1999. Retrieved 4 August 2008 from http://wwwwds.worldbank.org/external/default/WDSContentServer/WDSP/IB/2000/02/28/000 094946_00021405315280/Rendered/PDF/multi_page.pdf

World Bank. We are the world's largest external funder of education, 2006. Retrieved 22 May 2006 from http://digitalmedia.worldbank.org/tenthings/en/1.php

Xu, Hui. "Education Aid since the World War II: Problems and Trends.” Foreign Education Research 27(2000): 35-38. (In Chinese)

Xu, Jie. “On the Influence of the World Bank on China’s Market-Oriented University Autonomy Policy.” Jiangsu Higher Education 4(2006): 13-16. (In Chinese) Yang, Rui. Third Delight: The Internationalisation of Higher Education in China. New York: Routledge, 2002. 
Ye, Jun. “Comprehensive Sino-Foreign Educational Exchange.” In History of SinoForeign Educational Exchange, edited by Z. P. Tian. Guangzhou: Guangdong Education Press, 2004. (In Chinese)

Yu, Fu-zheng., Jiang, Bao. and Zhu, Xiao-yu. History of International Exchange and Cooperation in Education. Haikou, China: Hainan Publishing House, 2001. (In Chinese)

Zhang, Chen-chen. Transnational Higher Education in China: Why Has the State Encouraged Its Development? Master's dissertation, School of Education, Stanford University, 2003. 